INOBIS: Jurnal Inovasi Bisnis dan Manajemen Indonesia

Volume 1, Nomor 1, Desember 2017

Murtianingsih

\title{
Barriers to Small Business and The Possibility of Interelationship to Business Angels
}

\author{
Murtianingsih \\ Mahasiswa Program Doktor Manajemen Universitas Brawijaya
}

\begin{abstract}
Abstrak
Paper ini bertujuan untuk mengatahui berbagai hambatan bisnis kecil untuk tumbuh dan berbagai kemungkinan untuk menjadi bisnis angels sebagai alternatif untuk memperoleh sumber pendanaan. Serta mengetahui berbagai kebijakan di negara berkembang terhadap sektor usaha kecil dan bisnis angels.
\end{abstract}

Keywords: Teknologi Komunikasi, Value Creation, Role of Government

\section{Latar Belakang}

Bisnis kecil atau sektor mikro memiliki berbagai hambatan untuk dapat tumbuh dan suistanable, Okpara dan Wynn (2007), Robson dan Obeng (2008) dengan menguji hubungan antara kurangnya pembiayaan dan pertumbuhan usaha kecil, kurangnya keterampilan manajemen dan pertumbuhan usaha kecil, tantangan pasar dan pertumbuhan usaha kecil, dan masalah peraturan dan pertumbuhan bisnis kecil.

Littunen dan Tohmo (2003), Yasuda (2005), dan Yang dan Huang (2005) telah melihat faktor-faktor penentu pertumbuhan bisnis. Penelitan terhadap hal itu kurang menjelajahi masalah yang dihadapi oleh para pengusaha dalam kegiatan bisnis mereka (Orser et al, 2000;. Storey, 1994;. Smallbone et al, 1995). Hal ini penting untuk menemukan hambatan untuk pertumbuhan usaha kecil di British Columbia, Kanada karena masyarakat usaha kecil merupakan sumber penting dari penciptaan lapangan kerja (M2 Presswire,2008).

Usaha kecil memainkan peran integral dalam perekonomian Kanada. Pada tahun 2007, $98 \%$ bisnis usaha kecil yang beroperasi di British Columbia, menyediakan kerja bagi 1.048.000 orang (M2 Presswire, 2008, hal. 1). Di British Columbia bisnis kecil produk domestik bruto (PDB) menyumbang sepertiga dari PDB provinsi total, tertinggi di Kanada. usaha kecil dikirimkan lebih dari \$ 12000000000 senilai barang dagangan untuk tujuan internasional pada tahun 2006, lebih dari 37 persen dari total nilai barang yang diekspordari provinsi (M2 Presswire, 2008, hal. 1). Dari uraian tersebut menggmabarkan kontribusi usaha kecil terhadap PDB suatu negara.

\section{Tujuan}

Paper ini bertujuan untuk mengatahui berbagai hambatan bisnis kecil untuk tumbuh dan berbagai kemungkinan untuk menjadi bisnis angels sebagai alternatif untuk memperoleh sumber pendanaan. Serta mengetahui berbagai kebijakan di negara berkembang terhadap sektor usaha kecil dan bisnis angels. 
INOBIS: Jurnal Inovasi Bisnis dan Manajemen Indonesia

Volume 1, Nomor 1, Desember 2017

Murtianingsih

\section{Literature Review}

\subsection{Faktor-faktor yang mempengaruhi pertumbuhan bisnis kecil}

Usaha kecil diakui di seluruh dunia sebagai mesin pertumbuhan dan pengembangan. Faktor-faktor seperti kurangnya pembiayaan, kurangnya keterampilan manajemen, tantangan pasar, masalah peraturan, dan infrastruktur suatu negara mempengaruhi pertumbuhan usaha kecil. Zehir et al. (2006) menunjukkan bahwa pemasaran, manajemen, dan kemampuan sistem informasi berpengaruh positif secara signifikan terhadap pertumbuhan bisnis. Itu adalah, manajemen yang lemah, pemasaran, dan ketrampilan teknologi informasi pemilik usaha kecil memiliki dampak negatif pada pertumbuhan usaha kecil. Mambula (2002) juga menjelaskan bahwa kurangnya pembiayaan, regulasi (mis kebijakan dan sikap pemerintah) berdampak pada pertumbuhan bisnis.

Yang dan Xu (2006) menjelaskan bahwa ada perbedaan regional dalam kewirausahaan, pertumbuhan regional ekonomi, kegiatan kewirausahaan regional, dan pengembangan usaha kecil di Cina. Ini mungkin karena perbedaan dalam ketersediaan pembiayaan. Okpara dan Wynn (2007) juga menjelaskan bahwa pemilik bisnis di Afrika cenderung bergantung pada mereka sendiri atau tabungan keluarga karena akses ke modal merupakan tantangan bagi mereka.

Gill dan Biger (2012) menyatakan bahwa tantangan pasar, kurangnya pembiayaan, dan masalah peraturan menjadi hambatan pertumbuhan usaha kecil di Kanada. Hasil temuannya memungkinkan perwakilan pemerintah Kanada untuk melihat faktor-faktor tersebut di mana mereka dapat membuat Perbedaan - tantangan pasar, kurangnya biaya pendanaan, pendaftaran dan perizinan, dan tarif pajak usaha kecil. Untuk meminimalkan tantangan pasar, pemilik usaha kecil harus membuat jaringan dan mencari nasihat dari para pengusaha yang berpengalaman dalam usaha kecil sejenis.

Di antara faktor yang paling penting yang membuat hambatan adalah kurangnya pembiayaan. Ini direkomendasikan bahwa para pembuat kebijakan dan malaikat financers mempertimbangkan Grameen Bank Model untuk melawan masalah agunan dan pinjaman. Okpara dan Wynn (2007) menjelaskan bahwa Grameen Bank memberikan kredit mikro kepada orang miskin tanpa jaminan. Pemerintah Kanada harus meningkatkan keuangan untuk usaha kecil sehingga mereka dapat berhasil dalam pasar.

\subsection{Teknologi Komunikasi dan Informasi}

Web 2.0 adalah istilah yang diciptakan oleh O'Reilly (2005), yang digunakan untuk menggambarkan berbagai teknologi informasi dan komunikasi berbasis internet aplikasi (ICT). Web 2.0 mencakup heterogenitas aplikasi termasuk jaringan situs sosial, wiki, blog, podcast, pesan instan, forum diskusi, audio dan video conferencing, buku harian kelompok dan buku alamat, host kantor virtual, papan tulis dan sistem presentasi kolaboratif. kolaborasi tersebut telah lama menjadi fitur dari banyak usaha kecil masyarakat (Birley et al, 1991;.. Curran et al, 1993).

Brown dan Lockett (2004) mengkritik banyak literatur usaha kecil karena mengabaikan fakta bahwa perusahaan kecil sering cenderung menjadi bagian dari jaringan formal atau informal. Jaringan berbasis Kolaborasi merupakan karakteristik tertentu dari beberapa industri (konstruksi misalnya, produksi film dan seni pertunjukan). usaha seperti ini biasanya terjadi pada erat-merajut industri, sering di lokasi geografis tertentu, di mana calon peserta yang terkenal satu sama lain. Namun, TIK dari Web 2.0 berpotensi menawarkan semua 
INOBIS: Jurnal Inovasi Bisnis dan Manajemen Indonesia

Volume 1, Nomor 1, Desember 2017

\section{Murtianingsih}

perusahaan yang berarti mengatasi keterbatasan jarak. komunikasi online menawarkan prospek menggantikan kedekatan fisik dengan interaksi virtual dan bahkan keintiman sebagai dibuktikan dengan popularitas situs web seperti Facebook dan LinkedIn. Banyak alat Web 2.0 yang murah untuk memperoleh dan beroperasi dan memerlukan keahlian teknis kecil. Ada semakin banyak bukti anekdot bahwa beberapa usaha kecil telah menjadi awal pengadopsi dari Web 2.0 dan sedang mengembangkan pendekatan baru untuk kolaboratif bekerja dengan tujuan meningkatkan kemampuan mereka untuk melayani pelanggan mereka. Namun, sampai saat ini Fenomena yang muncul telah sedikit dipelajari.

Hinchcliffe (2010) dalam hasil diskusinya membuat ringkasan yang berguna mengenai manfaat potensial yang tersedia dari Web 2.0. Dia membedakan empat cara yang digunakan Web 2.0 untuk menciptakan nilai bisnis, yaitu pengurangan biaya, transformasi, pertumbuhan dan inovasi. Hal ini menunjukkan kategorisasi mungkin untuk manfaat yang tersedia dari Web 2.0 :

(1) Peningkatan intern efisiensi operasional: Web 2.0 menawarkan kemampuan untuk menurunkan biaya operasional dan meningkatkan produktivitas, baik secara individu maupun kolektif.

(2) Kemampuan Ditingkatkan: Web 2.0 membantu mengubah cara yang ada bekerja melalui kemampuannya untuk memungkinkan pekerja untuk terhubung dengan sumber pengetahuan dan keahlian baik di dalam dan di luar batas-batas organisasi tradisional.

(3) Lebih efektif komunikasi eksternal: Web 2.0 memfasilitasi pertumbuhan melalui kemampuan untuk meningkatkan komunikasi dengan pelanggan, yang ada dan potensial, memungkinkan persyaratan mereka untuk menjadi lebih baik dipahami dan dengan pemasok, kolaborator dan teman sebaya memungkinkan persyaratan mereka untuk lebih ditangani.

(4) Penawaran layanan Disesuaikan: Web 2.0 mendukung inovasi melalui kemampuannya untuk memungkinkan perusahaan untuk secara cepat menawarkan layanan baru yang disesuaikan untuk memenuhi spesifik kebutuhan pelanggan.

\subsection{Business Angels}

Pada umumnya, malaikat bisnis (BA) adalah perorangan yang memberikan modal ventura bagi usaha kecil sebagai pembiayaan putaran kedua. Setelah menggunakan semua dana dari keluarga atau teman-teman, mereka akan beralih ke BA untuk memberi bantuan, sebagai sumber penting dari modal untuk start-up sebelum meminta modal ventura (VC) untuk pembiayaan.

Dalam beberapa tahun terakhir, business angels telah berkembang pesat di China, yang bahkan menarik orang asing dari luar negeri china antusias, sedangkan pengusaha swasta adalah aktor utama, dan kelompok menjadi semakin besar. Pada waktu bersamaan, dengan pesatnya perkembangan China dan akumulasi cepat kekayaan warga, orang kaya meningkat.

Penelitian yang sistematis atas BA dapat ditelusuri kembali ke awal 1980-an, yang diprakarsai oleh sarjana Amerika Wetzel $(1981,1983)$ bekerja. Sejak itu, penelitian tentang BA telah berkembang pesat di seluruh dunia selama 1980-an ke 1990-an, dan studi di Amerika Serikat telah diadopsi dan dikembangkan di negara-negara di Amerika, Eropa dan Asia.

Implikasi dari penelitian BA pada akhirnya ditujukan untuk mempromosikan individu lebih mampu untuk menjadi BA, premis yang penting adalah analisis faktor pendorong 
INOBIS: Jurnal Inovasi Bisnis dan Manajemen Indonesia

Volume 1, Nomor 1, Desember 2017

\section{Murtianingsih}

utama BA. Jadi faktor pendorong untuk BA adalah topik hangat bagi para sarjana. Sebagai bidang waktu singkat, kurangnya teoritis, penelitian tentang faktor pendorong BA selalu berdasarkan sosial psikologi, ilmu perilaku dan teori-teori terkait lainnya. Dilihat dari penelitian yang ada, terdapat banyak kesamaan antara studi 'bahwa menjadi BA dipengaruhi oleh kombinasi faktor personal dan lingkungan.

Maula et.al (2005) menyatakan, bahwa kecenderungan, pengalaman dan keterampilan penting lebih dari demografi dalam menjelaskan kecenderungan untuk melakukan investasi informal sesuai Data dari Finlandia. Hasil Penelitian menunjukkan orang-orang yang pernah berhasil atau memulai bisnis, mampu memulai bisnis dan berkenalan dengan pengusaha, lebih mungkin untuk Bebas dalam penelitian BA Singapura, dan keterampilan memulai bisnis adalah penentu dominan untuk menjadi BA (Wong dan Ho, 2007).

Studi lain dari Kroasia, Hungaria dan Slovenia menunjukkan bahwa karakteristik demografi tradisional hanya bermain peran yang terbatas dalam investasi sementara sebagai pengalaman pemilik serta persekutuan antara investor dan pengusaha adalah faktor yang paling berpengaruh dalam penelitian tentangfaktor pendorong investasi resmi (Szerb et al., 2007).

\subsection{Private Equity and Value Creations}

Fokus pada pemahaman kontribusi relatif dari VC dan kelompok BA dalam penciptaan nilai penting bagi usaha teknologi tahap awal. Usaha tersebut dikenal karena jumlah uang tunai yang mereka butuhkan untuk berpindah dari awal sampai tahap awal mereka dan sangat bergantung pada modal finansial yang disediakan oleh BA dan VC. Secara tradisional, investor dianggap untuk mengisi ceruk antara teman dan pembiayaan keluarga dan investor modal ventura formal (Ibrahim, 2008). Semakin, diakui bahwa proses investasi tidak selalu seperti yang berurutan seperti yang diduga di masa lalu (OECD, 2011). Hal ini sebagian karena pertumbuhan kelompok investor, yang cenderung untuk berinvestasi pada tahap sedikit kemudian pembangunan usaha dari investor tradisional karena mereka dapat sumber daya, memfasilitasi investasi yang lebih besar sering diperlukan kemudian dalam pengembangan perusahaan. Ini juga mungkin karena VC telah secara dramatis bergeser proporsi mereka dari investasi dialokasikan untuk usaha tahap awal, dan proporsi penawaran meningkat dari 19,5\% menjadi 55,6\% antara tahun 2002 dan 2013 (PriceWaterhouseCoopers MoneyTree Report, 2013). Akibatnya, kelompok BA dan VC tahap awal sering berinvestasi pada tahap yang sama pembangunan usaha (Ibrahim, 2008; Shane, 2008).

\subsection{Angels Role in Governance}

Angels umumnya memiliki mekanisme kontrol yang fleksibel dan lebih memilih untuk mengadopsi pendekatan secara formal (Ibrahim, 2008; Van Osnabrugge, 2000) lebih mengandalkan pemerintahan relasional dari pemerintahan kontrak (Ehrlich et al., 1994). Hal ini menunjukkan bahwa kontrak Business Angels cenderung lebih ramah, memiliki hak kontrol lemah, menggunakan ketentuan kontrak, dan digunakan lebih dari transaksional dari sudut pandang titik kontrol (Goldfarb et al., 2009). Misalnya, Prowse (1998) berpendapat bahwa BA biasanya tidak menggunakan istilah canggih untuk perlindungan yang memadai dalam kontrak mereka, tetapi tingkat kecanggihan kontrak bervariasi tergantung pada keterlibatan aktif dan pengalaman sebelumnya investor BA. kelompok BA Formal cenderung lebih canggih dari Investor yang khas, mengadopsi norma-norma kontrak yang sering 
INOBIS: Jurnal Inovasi Bisnis dan Manajemen Indonesia

Volume 1, Nomor 1, Desember 2017

\section{Murtianingsih}

menyerupai yang tertulis secara terorganisir dalam pasar ekuitas swasta (Shane, 2008), dan ada beberapa bukti yang menunjukkan anggota kelompok investor yang mentor aktif.

\subsection{Angels and value added services}

Meskipun model Angels investasi merupakan sumber dana penting untuk usaha baru dan diperkirakan mewakili singa Pangsa investasi di usaha de-novo (Prowse, 1998), literatur akademik pada pembiayaan Angels tetap terbelakang. Sayangnya, tidak terdapat bukti di industri atau firm level tentang bagaimana pengaruh inovasi angels. Beberapa penelitian terbaru telah menyelidiki dampak dari investasi Angels pada kelangsungan hidup usaha (Kerr et al., 2014) dan perusahaan pasca kinerja IPO (Bruton et al.,2010). Di bawah ini, kami mengembangkan argumen teoritis yang menjelaskan mengapa Angles dapat menciptakan nilai bagi usaha teknologi, mengingat tiga dimensi yang sama ditujukan atas untuk VC.

\subsection{Micro Equity}

Bertanggung jawab secara sosial investasi (SRI) adalah proses investasi yang mengintegrasikan pertimbangan sosial, lingkungan dan etika dalam pengambilan keputusan investasi (Renneboog et al., 2008). Tidak seperti investasi konvensional, proses "menganggap konsekuensi sosial dan lingkungan investasi, baik positif maupun negatif, dalam konteks analisis keuangan yang ketat "(SIF, 2005). Ada banyak literatur yang berkembang pada SRI, meliputi pertumbuhan dana tersebut (Emerson, 2003;Jayne dan Skerratt, 2003; Sjostrom andWelford, 2009; Solomon et al.,2004; Valor et al, 2009.; Williams, 2007). Sejumlah faktor menjelaskan mengapa SRI telah berkembang di beberapa bagian dunia: keterlibatan dana pensiun, gerakan LSM, akar sejarah, agama, pelopor, hak pemegang saham minoritas, peluang untuk aktivisme pemegang saham dan CSR dan persyaratan pengungkapan (Sjostrom dan Welford, 2009; Valor et al, 2009.; Williams, 2007).

\subsection{Communications perspektive on Business Angels}

Hacklyn (2013) menyatakan Secara keseluruhan, data hasil wawancaranya menunjukkan bahwa rekening model bisnis memiliki dampak yang besar terhadap keputusan investasi investor tahap awal. Secara khusus, mereka memainkan peran penting dalam mediasi interaksi antara malaikat bisnis dan tim pendirian. Namun, dalam interaksi ini, malaikat bisnis memperhatikan hanya terbatas untuk konten yang disediakan oleh account tersebut. Mereka lebih suka menggunakan model bisnis sebagai taman bermain untuk interaksi komunikatif dengan tim pendiri di mana mereka mengidentifikasi karakteristik tim pendirinya.

Interaksi komunikatif tentang model bisnis memungkinkan BA untuk mengembangkan pemahaman yang lebih dalam kompetensi tim untuk berpikir dalam hal yang terkait dengan bisnis, kesediaan mereka untuk menerima saran, dan keterampilan komunikasi mereka. Secara umum, malaikat bisnis tahu bahwa model bisnis yang awalnya sangat asumsi-driven dan spekulatif dan membutuhkan terus menerus penyesuaian. Sejalan dengan ini, data wawancara lebih lanjut menunjukkan bahwa dalam BA biasanya mulai tidak mengharapkan rekening model bisnis akurat atau lengkap. Mereka menyadari sifat dinamis dari bisnis account Model dan tahu bahwa pengusaha sering menghadapi kognitif keterbatasan dalam membuat peluang bisnis di awal tahapan ini. Namun, sebelum memvalidasi peluang 
INOBIS: Jurnal Inovasi Bisnis dan Manajemen Indonesia

Volume 1, Nomor 1, Desember 2017

\section{Murtianingsih}

investasi lebih terstruktur, BA harus tertarik dalam ide bisnis dan merasa yakin tentang potensi keseluruhan kesempatan investasi.

\section{Conclusion}

Model bisnis memiliki potensi untuk menjelaskan kinerja perusahaan yang lebih tinggi dan keunggulan kompetitif. Inilah sebabnya mengapa baru-baru ini menjadi Konsep populer bagi para praktisi dan akademisi. Secara khusus, model bisnis menggambarkan bagaimana nilai ekonomi dapat diekstraksi dari teknologi menjanjikan dengan menerjemahkan input teknologi menjadi output pasar yang berharga. Pada tahap awal dari usaha baru, namun, model bisnis yang umum diwujudkan dalam rekening. Secara keseluruhan, akademisi mempertimbangkan rekening atau efektifitas sumber daya. Mereka menyarankan bahwa rekening memiliki kapasitas untuk menyampaikan identitas dipahami, untuk menguraikan logika peluang pemanfaatan, dan untuk menanamkan kewirausahaan usaha menjadi wacana kontekstual yang lebih luas (Martens et al.,2007).

\section{Daftar Pustaka}

Birley, S., Cromie, S., Myers, A., (1991), "Enterpreneurial networks: their emergence in Ireland and overseas", International Small Business Journal, Vol. 9 No. 4, pp. 56-74.

Brown, D.H., and Lockett, N., (2004), "Potential of critical e-application for engaging SMEs in e-business: e-provider perspective", European Journal of Information Systems, Vol. 13, pp. 21-34.

Bruton, G.D., Filatotchev, I., Chahine, S., Wright, M., (2010), Governance Ownership structure, and performance of IPO firms : The impact of different types of private equity investors and Institusional environments, Strateg, Manag, J. 31. 491-509

Curran, J., Jarvis, R., Blackburn, R.A., and Black, S., (1993), "Network and small firms: constructs methodological strategies and some findings", International Small Business Journal, Vol. 11 No.2, pp. 13-26.

Ehrlich, S.B., De Noble, A.F., Moore, T. and Weaver, R.R., (1994), "After the cash arrives : a comparative study of venture capital and private investor involvement in entrepreneurial firms", Journal of Business Venturing, Vol. 9 No. 1, pp. 67-82.

Emerson, J., (2003), The Blended Value Preposition: Integrating Social and Financial return, Calif, Manag, Rev. 45 (4), 35-51.

Gill Amarjit, Biger Nahum, ( 2012), "Barriers to small business growth in Canada", Journal of Small Business and Enterprise Development, Vol. 19 Iss. 4, pp. 656-668.

Goldfarb, B., Hoberg, G., Kirsch, D., Triantis, A., (2009), Does Angel Participation Matter? An anlysis oe Early Venture Financing, Unpublished Working Paper.

Hacklin Fredrik, Wallnofer Maria, (2013), The business model in entrepreneurial marketing : A Communication perspective on business angel, opportunity interpretation, Elsevier, ETH Zurich, Department of Management, Technology and economics, Weinbergstrase 56/58, CH 8092 Zurich, Switzerland.

Hinchcliffe, D., (2010), "Why all the fuss about Web 2.0?”, Infonomics, Vol. 2 No.1, pp. 2631.

Ibrahim, D.M., (2008), The (Not so) Puzzling behavior of angel investors. Arizona legal studies discussion paper 07-16, University of Arizona, James E. Roberts College of Law, AZ. 
INOBIS: Jurnal Inovasi Bisnis dan Manajemen Indonesia

Volume 1, Nomor 1, Desember 2017

\section{Murtianingsih}

Jayne, M.R., Skerrat, G., (2003), Socially resonsible investment in the UK-criteria that are used to evaluate suitability, Corp. Soc. Responsib. Environ. Manag. 10 (1), 1-11.

Kerr, W., Lerner, J., Schoar, A., (2014), The consequences of entrepreneurial finance : evidence from angel financings. Review Financ. Stud. 27, 20-55.

Littunen, H. and Tohmo, T. (2003), "The high growth in new metal-based manufacturig and business service firm in Finland", Small Business Economics, Vol. 21 No. 2, pp. 187200.

Mambula, C., (2002), "Perception of SME growth constraints in Nigeria", Journal of Small Busniness Management, Vol. 40 No. 1, pp. 58-65.

Martens, M. I., Jennings, J., E., \& Jennings. P.D., (2007), Do the stories they tell get them the money they need ? the role of entrpreneurial narratives in resource acquisition. Academy of management Journal 50 (5), 1107-1132.

OECD, 2011, Financing High-Growth Firms: The Role of Angel investors, OECD Publishing.

Okpara, J.O. and Wynn, P. (2007), “ Determinant of small business growth constraints in Sub-Saharan African economy”, S.A.M Advance Management Journal, Vol. 72 No. 2 , pp. 24-37.

Orser, B.J., Hogart-Scott, S., and Ridding, A.L., (2000), "Performance, firm size and management problem solving", Journal of Small Business Management, Vol. 38 No. 4, pp. 42-58.

O'Reilly, T., (2005), What is Web 2.0 : Design patern and business Models for the next generation of shoftware, available at : www. Oreily net.com/pub/a/oreilly/tim/news/ 2005/09/30/what-is web-2.0. html?page=1 (accesed 29 November 2010).

Presswire, M.2., (2008), Province of British Columbia : small business profile confirm sustained growth", M2, Presswire, p.1.

Prowse, S., (1998), Angel investor and the market for angel invesments, J. Bank, Finance. 22, 785-792.

Renneboog, L., Ter Horst., J., Zhang, C., (2008), Socially responsible investment: Institutional aspects, performance, and investor behavior, J. Bank, Financ. 32 (9), 1723-1742.

Robson, P.J. and Obeng, B.A. (2008), "The barriers to growt in Ghana", Small Business Economics, Vol. 30 No. 4, pp. 385-403.

Shane, S., (2008), The important of Angel investing in financing the growth of entrepreneurial ventures. Working paper 331, Small business administration, Office of advocacy, US.

SIF, (2005), Report and socially responsible investing trends in the United States. US Social Investment Forum. (http://www.socialinvest.org >)

Smallbone, D., Leigh, R., North, D., (1995), "The characteristics and strtaegies of high growth SMEs", International Journal of Entrepreneurial Behaviour and Research, Vol. 1 No. 3, pp. 44-63.

Storey, D.J., (1994), Understanding the small business sector, International Thomson Business Press, London.

Szerb, L., Rappai, G., Makra, Z., Terjesen, S., (2007), "Informal investment in transition economies: individual characteristics and clusters", Small Business and Economics, Vol. 28 No. 2/3, pp. 253-271.

Sjostrom, E., Welford, R., (2009), Facilitators and Impediments for socially responsible investment: a study of Hongkong, Corp. Soc. Responsib. Environ. Manag. 16 (5), 278288. 
INOBIS: Jurnal Inovasi Bisnis dan Manajemen Indonesia

Volume 1, Nomor 1, Desember 2017

\section{Murtianingsih}

Solomon, A., Solomon, J., Suto, M., (2004), Can The Uk experience provide lessons for the evolotion of SRI in Japan?, Corp. Gov. Int. Rev. 12 (4), 552-566.

Valor, C., de la Cuesta, M., Fernandez, B., (2009), Understanding demand for retail socially responsible invesment: a survey of individual investors and financial consultants. Corp. Soc. Responsib. Environ. Manag. 16 (1), 1-14.

Van Osnabrugge, M. and Robbinson, R.J., (2000), "Angel Investing : Matching Start up funds with start up Companies - The Guides fior Entrepreneurs, Individual Investor, and Ventures, Capitalist, Jossey-Bass, San Fransisco, CA.

Wetzel, W.E., Jr (1981), "Technovation and informal investor", Technovation, Vol.1 No.1, pp.15-30.

Wetzel, W.E., (1983), “Angels and informal risk capital”, Sloan Management Review, Vol. 24 No. 4 , pp. 23-24.

Williams, W., (2007), Some determinants of the socially responsible investment decision : a cross - country study. J., Behav. Finance. 8 (1), $43-57$.

Wong, K.P., and Ho, Y.P., (2007), "Characteristics and determinants of informal investment in Singapore", Venture Capital: an International Journal Entrepreneurial Finance, Vol.9 No. 1, pp.43-70.

Yang, C.H., and Huang, C.H., (2005), "R\&D, size and growth in Taiwans electronics industry", Small Business Economics, Vol. 25 No. 5, pp. 477-87.

Yasuda, T. (2005), "Firm growth, size and behavior in Japanese manufacturing", Small Business Economics, Vo. 24 No. 1, pp. 1-15.

Zehir, C., Acar, A.Z., and Tanriverdi, H., (2006), "Identifying organizational capabilities as predictors of growth and business performance", The Business Review, Vol. 5 No. 2 , pp. 109-16. 